\title{
Improving the use of remote laboratories. The case of VISIR at Universidad Nacional de Rosario
}

\author{
Federico Lerro \\ Facultad de Ciencias Exactas, Ingeniería y \\ Agrimensura \\ Universidad Nacional de Rosario Rosario, \\ Argentina \\ flerro2@yahoo.com.ar \\ Miguel Angel Plano \\ Facultad de Ciencias Exactas, Ingeniería y \\ Agrimensura \\ Universidad Nacional de Rosario \\ Rosario, Argentina \\ mplanoster@gmail.com \\ Javier Garcia-Zubia \\ Facultad de Ingeniería \\ Universidad de Deusto \\ Bilbao, España \\ zubia@deusto.es
}

\author{
Susana Teresa Marchisio \\ Facultad de Ciencias Exactas, Ingeniería y \\ Agrimensura \\ Universidad Nacional de Rosario \\ Rosario, Argentina \\ smarch@fceia.unr.edu.ar \\ Claudio Merendino \\ Facultad de Ciencias Exactas, Ingeniería y \\ Agrimensura \\ Universidad Nacional de Rosario \\ Rosario, Argentina \\ claudiomerendino@hotmail.com \\ Unai Hernández-Jayo \\ Facultad de Ingeniería \\ Universidad de Deusto \\ Bilbao, España \\ unai.hernandez@deusto.es
}

\author{
Sonia Beatriz Concari \\ Facultad de Ciencias Exactas, Ingeniería y \\ Agrimensura \\ Universidad Nacional de Rosario \\ Rosario, Argentina \\ sconcari@fceia.unr.edu.ar \\ Gastón Saez de Arregui \\ Facultad de Ciencias Exactas, Ingeniería y \\ Agrimensura \\ Universidad Nacional de Rosario \\ Rosario, Argentina \\ gsaez218@gmail.com \\ Gustavo Alves \\ Politécnico do Porto \\ Instituto Superior de Engenharia \\ Porto, Portugal \\ gca@isep.ipp.pt
}

\begin{abstract}
The present work originates in the Project "Educational Modules for Electric and Electronic Circuits Theory and Practice following an Inquiry-based Teaching and Learning Methodology supported by VISIR", carried out with the support of the Erasmus+ Programme. Remote labs can provide a framework where physical experiments can be developed for STEM (Science, Technology, Engineering and Mathematics) education. Although remote labs have been in use for over a decade now in several countries and levels of education, their use is not yet being generalized in Latin America. Through the VISIR+ International Cooperation Project from the Erasmus+ Programme, five higher education institutions from Latin America have incorporated de VISIR remote lab in order to carry out experiments with electric and electronic circuits. In the present work, the results of the study developed at Universidad Nacional de Rosario within the framework of the aforementioned project are shown.
\end{abstract}

Keywords—remote labs; STEM; experimentation; VISIR

\section{INTRODUCTION}

The VISIR+ project "Educational Modules for Electric and Electronic Circuits Theory and Practice following an Inquirybased Teaching and Learning Methodology supported by VISIR" was carried out with the support of the European Union ERASMUS+ programme, under the coordination of the Polytechnic of Porto (IPP, Portugal). Within the framework of that Project, developed between 2015 and 2018 by a consortium consisting of institutions from Argentina, Austria, Brazil, Spain, Portugal and Sweden, it was sought to spread good teaching practices as a result of cooperation and exchange in the fields of the teaching of electric and electronic circuits, by using the so-called "Virtual Instrument Systems In Reality" (VISIR) [1] [2], name given to the remote laboratory developed by Ingvar Gustavsson, at the Blekinge Institute of Technology (BTH), Sweden.

This Project made it possible for the VISIR remote laboratory to be set up in five Higher Education Institutions (HEI), three of them in Brazil and two in Argentina, thus allowing about three hundred teachers and over 1,500 students [4] from different universities and high school institutions in Latin America (LA) to be part of the VISIR users community since the curricular integration of this resource in coherence with inquiry learning approaches. The setting up of the laboratory in every LA institution was performed with the assistance of a team from BTH, which has ample experience with VISIR system usage, installation and technical issues.

The present work describes the institutional experience of Universidad Nacional de Rosario (UNR), born from this cooperation with European Universities and LA institutions within the framework of the VISIR+ Project. Teachers and researchers who have taken part of the project as members, academic authorities, teachers and students at FCEIA-UNR, as well as two UNR associated partners, and others, with which the FCEIA working team keeps close cooperation are involved in it [5]. All of them have taken part, as the case may be, of all or some of the scheduled activities planned for the Project.

In the following sections, those participation venues are described, and results obtained are reported. But before that and considering UNR as a case study, there is a short featuring of the institution from the point of view of its working background in the fields of remote laboratories, both as regards topics linked to technical development as well as their use in teaching contexts.

This work was carried out with the economic support of the European Commission through Project 561735-EPP-12015-1-PTEPPKA2-CBHE-JP and by Universidad Nacional de Rosario, through Project PID 1ING505. 


\section{MethodOLOGY}

\section{A. Background of UNR on Remote Laboratories}

UNR was part of the VISIR + Project, along with two associated partners: Instituto Politécnico Superior (IPS), from UNR, and Facultad Regional Rosario (FRRo) from Universidad Tecnológica Nacional (UTN).

Inside UNR, the Remote Laboratories area is part of Facultad de Ciencias Exactas, Ingeniería y Agrimensura (FCEIA), an academic unit created almost 90 years ago and which, among others, bears responsibility for the teaching of six Engineering careers - among which there are Electric and Electronic Engineering, three Bachelor's degrees in Basic Sciences (Physics, Mathematics and Computer Sciences) and two university teacher training careers, in Mathematics and Physics, apart from several postgraduate careers, two of which have been taught through the e-learning modality since 1999 . All of this, plus the continuous search for improving training, has given birth to teams of teachers and researchers trained in experimental sciences and engineering education at FCEIA; many of them doing research in the area of teacher training and curricular incorporation of teaching resources based on Information and Communication Technologies (ICT).

So, although in Argentina the spreading of remote laboratories in teaching is not large-scaled, at FCEIA from UNR there were previous experiences that refer to the development and use of remote laboratories with educational purposes [6], well accepted by students [7]. One of these laboratories, the so called "Electronic Physics Remote Laboratory" (EPRL) dates back to 2007 [8]; the other laboratory is the one called "Solar thermal energy mobile remote laboratory. Technological innovation for tests/solutions leading to energy saving" [9], which was chosen with distinction to be shown at the national fair INNOVAR 2012.

Beyond all improvements to the interface and innovations in designs in order to optimize the features concerned [10], at an institutional level, those first developments evolved into the current management system of virtual and remote laboratories called LabRem-FCEIA-UNR [11]. This system manages users from both remote laboratories mentioned before and from VISIR, as well as the federation with WebLab-Deusto and with RexLab from Universidad Federal de Santa Catarina, in Brazil, thus enabling the admission of any of all of them from a unique access. In addition, LabRem-FCEIA-UNR manages the permissions per laboratory thus allowing for the creation of groups of users at different levels (manager, teachers and students) and makes it possible for new users to log in by using their social network accounts. (Facebook and Twitter) [12].

All achieved so far as regards technical innovations, educational research and even, the transfer of results to other institutions by the team at UNR [13], has been, besides, the product of a history of exchanges and collaborations in which some of the partners from the international consortium that carried out the VISIR+ Project have not been outsiders. [14].

\section{B. Project activities as sources of data}

At the end of the project, one of the expected results was a set of educational modules comprising the use of hands-on, simulated and remote labs, following an inquiry-based methodology. It implied the inclusion of the VISIR remote lab in theoretical and practical lessons with students, within a variety of courses related to electric and electronic circuits in LA institutions. In order to fulfil that objective, the activities planned for the VISIR+ Project included three training actions (TA) and a technical workshop (TW). The first training action (TA1) took place in Sweden and the others were developed, at different moments of the project, in the premises of each LA institution or partner institution. In a brief summary, those activities were organized in order to:

(1) Train the teachers in how to use and integrate the VISIR remote lab into their courses, following an inquirybased teaching and learning methodology, which combines other educational resources like hands-on labs, simulations and calculus. They refer to TA1, TA2 y TA3.

(2) Train non-academic staff members of the partner who received the VISIR remote lab. They refer to TW

(3) Collect evidence of the teaching implementations, for later analysis and report in a number of dissemination events and publications.

In this regard, two kinds of surveys were developed: "Students" Satisfaction Questionnaire" and "Teachers' Satisfaction Questionnaire", with a subsequent analysis of students' and teachers' opinions respectively. These questionnaires were built and validated [15] by members of the VISIR+ Project, responsible for Work Package 3, belonging to the Politécnico do Porto (IPP), Portugal, and to the Instituto Rosario de Investigación en Ciencias de la Educación (IRICE), Argentina.

Quantitative and qualitative data was gathered. Among the first pieces of information, in this present work are highlighted those which refer to impact in terms of institutions and courses developed, including number of teachers and students involved. Also, regarding didactic implementations using VISIR, some results of the tests on them are offered.

\section{The first training action in Rosario: TA2}

At UNR, the first training action in the framework of the VISIR+ project took place at FCEIA in September 2016. The training lasted for three days, combining oral presentations, workshop modality and practical activities with VISIR.

They were led by two research professors from Deusto University, who are experts in the use of VISIR, plus the three UNR teachers with wide experience in didactical use of remote laboratories in Electronic Engineering courses. There was also one researcher from Instituto Rosario de Investigación en Ciencias de la Educación (IRICE), member of the VISIR+ Project, with the aim of taking record of everything that happened in the training sessions.

This TA at FCEIA targets at all teachers with lecture duties in Engineering courses related to electric and electronic circuits, plus two representatives from each of the two UNR 
associated partners. As this training action was also considered one key moment for dissemination at a regional level, there were also guest academic authorities, PhD students and teachers from other institutions near UNR.

Selected by Consejo Federal de Decanos de Ingeniería (CONFEDI), three teachers, each one from three different Argentine Universities: Universidad Nacional de la Patagonia San Juan Bosco (UNPSJB), Universidad Nacional de Mar del Plata (UNMP) and Universidad Nacional de San Luis (UNSL), were included as trainees, with the aim of extending the scopes of the project to other regions within the country.

Due to some administrative delays related to the import process, UNR still lacked the necessary equipment to support training. This inconvenience was overcome by using the VISIR platform from Deusto University (DU) [16], via Internet. TA2 started with some explanation about what a remote laboratory is, thus distinguishing it from a virtual lab. It also includes application examples selected from those available on Web Lab Deusto with electric and electronic circuits. The teachers focus on both, technical and teaching aspects, especially in order to scaffold students' learning and foster their autonomy, namely by allowing them to conduct real experiments over the Internet.

Once the training was completed, and in order to favour both the involvement of teachers and the immediate application of what was learned to the classroom context, attendees were asked to plan an educational activity by using VISIR, contextualized in their own subject, career and institution. The passing of this final integrative learning activity was a requirement for certification of the approval of the training performed. These teachers' productions gave birth to most didactic implementations with VISIR carried out at UNR and associated institutions.

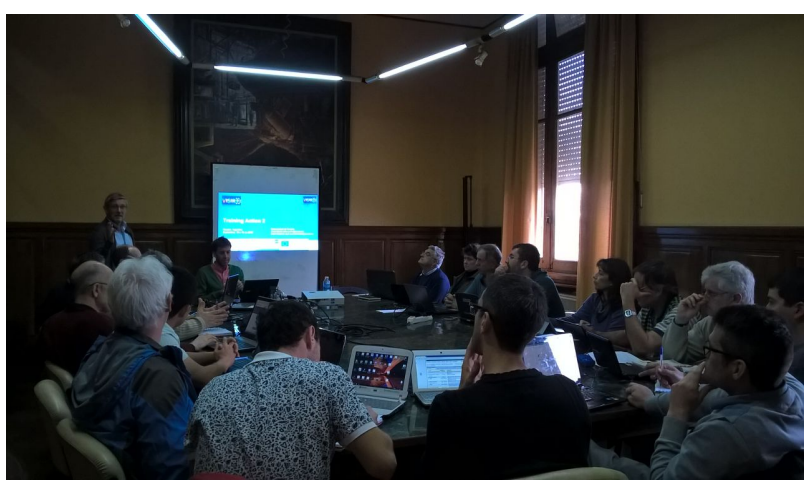

Figure 1 - A moment of the TA2 at the FCEIA-UNR

\section{The second training action in Rosario. The TA3}

TA3 was designed to be held in one Associated Partner of each Latin American Institution. Its philosophy was the multiplying effect: local teachers who had already used it, would more easily deliver those sections, contextualizing them according to their constraints, motivating their colleagues (from their Institution and from their Associated Partner Institution) to use VISIR [4].
In the case of UNR the TA3 was developed at Facultad regional Rosario (FRRo) from UTN, for three days, in October 2017. For this TA, UNR counted on its own equipment to support training. It combined oral presentations and workshop modality with practical activities using VISIR.

The oral presentation was used both to introduce the main topics linked to the technical and teaching features of VISIR, as well as to describe the so-called "cases of use". As regards the latter, the teams of teachers in charge of the seven didactic implementations arising from TA2 were invited as lecturers for them to share their own experiences at using VISIR. During a whole day, they explained the fundamentals and motivations, which led their teaching designs with the inclusion of VISIR, starting from a brief description of the course or subject and of their addressees. They also introduced the aims expected at including VISIR and the articulation of its use either by combining it or not with the use of other teaching resources, the activities required from students and learnings evaluation strategies. Finally, and making way for questions, the lecturers shared their own assessments about the achievements, advantages and difficulties which arouse from the analysis of what had been done. In the same way as in TA2, once the training was completed, attendees were asked to plan an educational activity by using VISIR, contextualized in their own subject, career and institution.

\section{E. The technical Workshop}

The Technical Workshops (TW) were also delivered in each LA institution after the setting up of the VISIR equipment. This action meant to train the technical staff that would be responsible for maintaining the VISIR system working and for helping teachers implementing the chosen circuits on VISIR.

At UNR, the TW was led by two professors from the VISIR lab developing team from Bleckinge Institute of Technology (BIT), in August 2017 [17]. Although the natural addressees of the TW were the members of the technical staff at UNR, this institution arranged a briefing for teachers and students from FCEIA and from associated institutions, which showed interest in getting to know the technical features of VISIR.

\section{RESULTS}

\section{A. From the training actions}

Table I shows the numbers of attendees involving UNR.

TABLE I. ATTENDEES IN TRAINING AND TW ACTIONS INVOLVING UNR

\begin{tabular}{|c|c|c|c|}
\hline & Place/Date & Addressees & Amount \\
\hline TA1 & $\begin{array}{c}\text { Karskrona (Sweden), } \\
\text { February 2016 }\end{array}$ & $\begin{array}{c}\text { Academic staff from } \\
\text { UNR }\end{array}$ & 3 \\
\hline TA2 & $\begin{array}{c}\text { FCEIA-UNR } \\
\text { September 2016 }\end{array}$ & $\begin{array}{c}\text { Teachers from FCEIA } \\
\text { and associated institutions }\end{array}$ & 26 \\
\hline TA3 & $\begin{array}{c}\text { FRRo-UTN } \\
\text { October 2017 }\end{array}$ & $\begin{array}{c}\text { Teachers from FCEIA } \\
\text { and associated institutions }\end{array}$ & 27 \\
\hline TW & $\begin{array}{c}\text { FCEIA-UNR } \\
\text { August 2017 }\end{array}$ & $\begin{array}{c}\text { Technical Staff, Teachers } \\
\text { and Students }\end{array}$ & 30 \\
\hline \multicolumn{3}{|c|}{ Total trained addressees } & 86 \\
\hline
\end{tabular}


Numbers in Table I are important in terms of percentage if we consider that for the whole of the training actions carried out at the five LA institutions, the number of attendee teachers was 274. [4].

\section{B. Concerning the didactical implementations}

TA2 lasted for three days. However, the activity was designed over several months afterwards. Teachers at Deusto University as well as the team working at UNR supported the activity of those attendees who decided to carry out didactical implementations with VISIR.

At UNR, the teaching teams from four curricular subjects, one belonging to the general basic stage for the Engineering careers and three from the Electronic Engineering career (EE) planned, although with different timetables and sticking them to their own needs, the curricular inclusion of VISIR in their regular courses.

The most significant experiences in this institution are the ones corresponding to the following subjects: Circuits Theory (CT), Physics of Electronic Devices (PED) and Electronic Devices and Circuits I (EDC), all of them belonging to the block of Basic Technologies of the EE career [18]. In all these cases, it is about training subjects of competences in the analysis of signals, electronic devices and linear and nonlinear circuits. They are in the curriculum between the second and the third year and, altogether, they make up a curricular section formed by subjects with consecutive teachings and sequential contents. The three courses share the search for teaching alternatives that reinforce the unavoidable value of experimenting for the development of competences in Engineering and the use of technologies based on the Internet, which facilitate flexible learning moments and spaces with student-centred methodologies.

Apart from everything done in those subjects, it is necessary to mention the experience at FCEIA carried out in a committee of the subject Physics III in the Engineering basic stage. Although the number of students taking part of that experience was really small, all done allowed students of Engineering at UNR living as far as $103 \mathrm{~km}$ away from Rosario to develop activities involving experimentation with RLC circuits without the need of attending the Physics lab at FCEIA.

On the other hand, some proposals for didactic implementations done by teachers from both partner institutions: Facultad Regional Rosario (FRRo) from UTN and Instituto Politécnico Superior (IPS) from UNR arouse, as well as other two institutions whose teachers took part in TA2: Universidad Nacional de la Patagonia San Juan Bosco (UNPSFB) and Universidad Estatal a Distancia (UNED) from Costa Rica. In all four institutions courses and workshops involving different aims and addressees with the use of VISIR were fulfilled. Particularly it was about: 1) the implementation of remote experimentation by using VISIR in a Physics subject at high-school level, developed at Instituto Politécnico Superior from UNR [19-21]; 2) the incorporation of a remote practice with VISIR in order to round off traditional experimental training in the subject Circuits Theory I of the Electronic Engineering career at UNPSFB [22]; 3) the incorporation of VISIR to carry out experimental practices thus complementing traditional laboratory in a subject of Physics for students of engineering at FRRo from UTN [23]; 4) a teachers' training workshop about the use of remote labs for Physics teaching at university and high-school level developed within the framework of the II Seminario de la Latin American Science Education Research Association (LASERA) in Costa Rica, [24] and a third workshop coordinated collaboratively with another teacher from UNR, during the XX Physics Education Forum (REFXX), in Argentina.

Table II summarizes the information about didactic implementations with the use of VISIR arising from the participation of UNR in the VISIR+ project. It belongs to the period of development of the project involving years 2016 to 2018, whose addressees were university and high school students. It is shown the kind of course, clarifying the number of editions over the period concerned, the educational level aimed at, its institutional placement and number of participants $(\mathrm{N})$, together with a brief description of contents dealt with and the kind of experimental activity carried out in each case.

TABLE II. DIDACTICAL IMPLEMENTATIONS WITH STUDENTS

\begin{tabular}{|c|c|c|c|}
\hline $\begin{array}{l}\text { Curse / } \\
\text { Subject }\end{array}$ & $\begin{array}{c}\text { Career / } \\
\text { Institution }\end{array}$ & $\begin{array}{c}\text { Content tackled with VISIR } \\
\text { Learning activity }\end{array}$ & $\mathbf{N}$ \\
\hline $\begin{array}{l}\text { Circuits } \\
\text { Theory } \\
\text { (2 editions) }\end{array}$ & $\begin{array}{l}2^{\text {nd }} \text { Course } \\
\text { Electronic } \\
\text { Engineering } \\
\text { UNR }\end{array}$ & $\begin{array}{l}\text { - Height power factor correction. } \\
\text { Temporal transitional evolution in } \\
\text { a second order circuit - RLC }\end{array}$ & 30 \\
\hline $\begin{array}{l}\text { Physics of } \\
\text { Electronic } \\
\text { Devices } \\
\text { (3 editions) }\end{array}$ & $\begin{array}{l}3^{\text {rd }} \text { Course } \\
1^{\text {st }} \text { Semester } \\
\text { Electronic } \\
\text { Engineering } \\
\text { UNR }\end{array}$ & $\begin{array}{l}\text { - Study of amplification with } \\
\text { transistors. } \\
\text { Basic circuits with polarization } \\
\text { and signal with transistors. Study } \\
\text { of amplitude and frequency } \\
\text { dependence. }\end{array}$ & 45 \\
\hline $\begin{array}{l}\text { Electronic } \\
\text { Devices } \\
\text { and } \\
\text { Circuits I } \\
\text { (1 edition) }\end{array}$ & $\begin{array}{l}3^{\text {rd }} \text { Course } \\
2^{\text {nd }} \text { Semester } \\
\text { Electronic } \\
\text { Engineering } \\
\text { UNR }\end{array}$ & $\begin{array}{l}\text { - Testing of RC circuits in low and } \\
\text { high pass configurations. }\end{array}$ & 12 \\
\hline $\begin{array}{l}\text { Physics III } \\
\text { (1 edition) }\end{array}$ & $\begin{array}{l}2^{\text {nd }} \text { Course } \\
1^{\text {st }} \text { Semester } \\
\text { Engineering } \\
\text { Basic Stage } \\
\text { UNR }\end{array}$ & $\begin{array}{l}\text { - Study of RLC basic circuits with } \\
\text { AC power supply. }\end{array}$ & 3 \\
\hline $\begin{array}{l}\text { Physics IV } \\
\text { ( } 2 \text { editions) }\end{array}$ & $\begin{array}{l}4^{\text {th }} \text { Course } \\
\text { High Level } \\
\text { School } \\
\text { IPS - UNR }\end{array}$ & $\begin{array}{ll}\text { - } & \text { Kirchhoff's Laws } \\
\text { - } & \text { Promoting motivation } \\
\text { and Dour DC circuits. Only resistors } \\
\text { were used. }\end{array}$ & 119 \\
\hline $\begin{array}{l}\text { Physics II } \\
\text { (1 edition) }\end{array}$ & $\begin{array}{l}2^{\text {nd }} \text { Course } \\
\text { Engineering } \\
\text { Basic Stage } \\
\text { FRRo- UTN }\end{array}$ & $\begin{array}{l}\text { - Teaching of Ohm's law by using } \\
\text { VISIR platform. } \\
\text { - Experiments with DC circuits }\end{array}$ & 17 \\
\hline $\begin{array}{l}\text { Circuits } \\
\text { Theory I } \\
\text { (1 edition) }\end{array}$ & $\begin{array}{l}2^{\text {nd }} \text { Course } \\
\text { Electronic } \\
\text { Engineering } \\
\text { UNPSJB } \\
\end{array}$ & $\begin{array}{l}\text { - Analysis and interpretation of the } \\
\text { forced temporary answer of an } \\
\text { RLC circuit. }\end{array}$ & 11 \\
\hline \multicolumn{3}{|c|}{ Total number of students who used VISIR in the different courses } & 237 \\
\hline
\end{tabular}


All didactic implementations aimed at students were developed on pre-existing courses. At UNR, the updated courses consisted of modifying the course curricula in order to use different resources simultaneously: hands-on lab, simulations, remote lab and calculus. The main objective was to develop complementary experimental competences and to consolidate theory and practice in electric and electronic topics. Also, in the case of high school levels, remote experimentation with VISIR was used in one of the Physics courses, in order to motivate students of technical careers not directly linked to Electricity, in the study of fundamental concepts, such as Ohm and Kirchhoff's laws. In all cases, students' training was delivered by each teacher in class, and also using tutorial videos. All the courses have been updated, either by reformulating their teaching methodology more aligned with developing an inquiry-based learning and/or by providing students with extra resources to practice experimental work in and out of class.

Table III summarizes the information about didactic implementations with VISIR arisen from the participation of UNR in the VISIR+ Project, aimed at teachers, corresponding to the period of development of the Project (2016 - 2018). Teachers from UNED and UNR coordinated them. It is about teacher training workshops whose aims were to promote the introduction of RLs in Physics teaching, to motivate teachers to include RLs in their classrooms as well as to introduce VISIR for electric circuit's experimentation.

TABLE III. DIDACTIC IMPLEMENTATIONS AIMED AT TEACHERS

\begin{tabular}{|c|c|c|c|}
\hline $\begin{array}{c}\text { Collaborating } \\
\text { institution }\end{array}$ & $\begin{array}{c}\text { Implementation } \\
\text { context }\end{array}$ & $\begin{array}{c}\text { Content approached with } \\
\text { VISIR. Learning activity. }\end{array}$ & N \\
\hline UNED & $\begin{array}{c}\text { LASERA } \\
\text { academic forum in } \\
\text { San José (Costa } \\
\text { Rica) }\end{array}$ & $\begin{array}{c}\text { Five electrical circuits with } \\
\text { resistors to study Ohm's } \\
\text { Law }\end{array}$ & 18 \\
\hline UNED - UNR & $\begin{array}{c}\text { REFXX academic } \\
\text { forum in } \\
\text { Concordia } \\
\text { (Argentina) }\end{array}$ & $\begin{array}{l}\text { Five electrical circuits with } \\
\text { resistors to study Ohm's } \\
\text { Law }\end{array}$ & 11 \\
\hline \multicolumn{3}{|c|}{ Total number of teachers who used VISIR in workshops } & 29 \\
\hline
\end{tabular}

\section{Concerning the implementations}

One of the tools used to evaluate didactic implementations was the "Students' Satisfaction Questionnaire." It is made up of 20 items, Likert scale 1 to 4 , where 4 means "I totally agree" and 1 means "I don't agree", plus two open questions. The questions included in the questionnaire are linked to four analysis aspects or dimensions, which make it possible to value satisfaction. They are:

- D1. Learnings as perceived by students themselves;

- D2. VISIR acceptance;

- D3. Technical or time limits to use VISIR;

- D4. Teacher's guide as perceived by the student himself for the development of the activity with VISIR.
As regards the didactic implementations carried out in the three regular courses of the Electronic Engineering career at UNR, the present work shows results arising from the use of the "Students' Satisfaction Questionnaire" regarding D, "Learnings as perceived by students themselves". Table IV summarizes the results achieved.

TABLE IV. REPLIES IN AGREEMENT OR IN TOTAL AGREEMENT TO THE STUDENTS' SATISFACTION QUESTIONNAIRE IN REGULAR COURSES AT FCEIAUNR

\begin{tabular}{|c|c|c|c|c|}
\hline & & CT & PED & EDC \\
\hline Q1 & $\begin{array}{l}\text { VISIR helped me understand } \\
\text { better some contents of the } \\
\text { subject }\end{array}$ & $76,7 \%$ & $71,2 \%$ & $58,4 \%$ \\
\hline Q2 & $\begin{array}{l}\text { I tried the experiments several } \\
\text { times if I considered the results } \\
\text { looked unfamiliar. }\end{array}$ & $86,6 \%$ & $80,0 \%$ & $83,4 \%$ \\
\hline Q3 & $\begin{array}{l}\text { I think I can handle the remote } \\
\text { lab very well. }\end{array}$ & $73,3 \%$ & $71,1 \%$ & $50,0 \%$ \\
\hline Q4 & $\begin{array}{l}\text { I think I can solve many real } \\
\text { electricity problems. }\end{array}$ & $43,3 \%$ & $57,7 \%$ & $50,0 \%$ \\
\hline Q5 & $\begin{array}{l}\text { I managed to use scientific } \\
\text { concepts to explain the results of } \\
\text { the experiments. }\end{array}$ & $93,3 \%$ & $97,8 \%$ & $75,0 \%$ \\
\hline
\end{tabular}

The tabulated values belong to the options of replies "I agree" or "I totally agree". They show high degree of satisfaction among these students. The values corresponding to assertions Q1, Q3 and Q5 imply a meta learning, while the ones corresponding to assertion Q2, show that students have fulfilled the experiences thoughtfully. About half the students considers that, even after carrying out the activities suggested with the use of VISIR, they are not sure about solving many real electricity problems (assertion Q4), which is understandable: doing real experiments with a RL is a learning activity which must be supplemented with others along the whole career.

The implementations carried out in the other associated and collaborating institutions, show that it is possible to introduce VISIR in regular courses and in teachers' training workshops, and that the greatest advantage "is accessibility students can access from home/ from anywhere/ anytime, allowing them to study and perform their tasks at their own pace (allowing them to repeat it as many times as they need)." [25], as derived from students' anonymous replies to the Students' Satisfaction questionnaire.

\section{CONCLUSIONS}

The results of all these actions show the achievement of one of the VISIR+ project aims: to spread good teaching practices as a result of cooperation and exchange in the fields of electric and electronic circuits teaching. Within the project framework, the mentioned regular courses at FCEIA-UNR included the VISIR RL in their own curricular activities. About 40 users were created for TA2 and since TA3 (including it) there have been 162 new users in the LabRemFCEIA system. So far 1327 accesses to the VISIR at FCEIA have been counted since its setting up, with an average of 
almost 3-minute use per access. 309 circuits are recorded to be stored in the system by users for their streaming access.

Apart from FCEIA itself, as a result of the actions developed by the team of this institution within the project framework, teachers and students from three other universities have also used VISIR: UTN and UNPSJB, both from Argentina, and UNED from Costa Rica.

The continuity of the teaching implementations with VISIR is supported in the formulation, already in course, of cooperation projects among the institutions that are still collaborating more closely with UNR.

\section{ACKNOWLEDGMENTS}

The authors would like to thank the support of the VISIR Community.

\section{REFERENCES}

[1] C. Viegas, G. R. Alves, M. A. Marques, N. Lima, M. Felgueiras, R Costa, A. Fidalgo, M. Pozzo, E. Dobboletta, J. García-Zubía, U. Hernández-Jayo, M. Castro, F. García-Loro, D. Zutin, C. Kreiter, "VISIR+ Project - Preliminary results of the training actions", 14th Remote Engineering and Virtual Instrumentation (REV) Conference, New York, NY, USA, 15-17 March 2017

[2] G. Alves, A. Fidalgo, M. Marques, M. Viegas, M. Felgueiras, R. Costa N. Lima1, W. Kulesza, J. Zubía, M. Castro, A. Pester, A. Pavani, J. Silva, L. Schlichting, S. Marchisio, R. Fernández, V. Oliveira, M. Pozzo, "Using a 3-tier Training Model for Effective Exchange of Good Practices in as ERASMUS+ Project," 12th Annual International Technology, Education and Development Conference (INTED), Valencia, Spain, 5-7 March 2018

[3] I. Gustavsson, J. Zackrisson, T. Olsson, "Traditional Lab Sessions in a Remote Laboratory for Circuit Analysis," in Proceedings of the $15^{\text {th }}$ EAEEIE Annual Conference on Innovation in Education for Electrical and Information Engineering, Sofia, Bulgaria, 2004.

[4] Final Report VISIR+ Project.

[5] S. Concari, S., S. Marchisio. "Redes de cooperación internacional en comunidades virtuales para la investigación, el desarrollo y la capacitación. En: Políticas universitarias, comunidades virtuales y experiencias innovadoras en educación. S. Copertari y N. Sgreccia (Compiladoras). 121-157, Laborde Editor, Rosario, October, 2018.

[6] S. Marchisio, F. Lerro, F., O. Von Pamel. "Empleo de un laboratorio remoto para promover aprendizajes significativos en la enseñanza de los dispositivos electrónicos". Revista Pixel Bit, No. 38. Enero 2011. ISSN: 1133-8482. Sevilla, España.2011. http://www.sav.us.es/pixelbit.

[7] F. Lerro, S. Marchisio. "Preferences and Uses of a Remote Lab from the Students' Viewpoint". International Journal of Online Engineering (IJOE) Vol $12 \mathrm{~N}^{\circ} 3$ pp. 53-57. 2016.

[8] F. Lerro, M. Protano. "Web-based Remote Semiconductors Devices Testing Laboratory". International Journal of Online Engineering (iJOE) Vol. 3, No. 3. 2007. http://www.i-joe.org

[9] G. Saez de Arregui, M. Plano, F. Lerro, L. Petrocelli, S. Marchisio, S Concari, V. Scotta. "A Mobile Remote Lab System to Monitor in Situ Thermal Solar Installations". International Journal of Interactive Mobile Technologies. (iJIM). V7; 1; Start page: 31. ISSN1865-7923. 2013.

[10] F. Lerro, S. Marchisio, E. Perretta, M. Plano, M. Protano. "Using the Remote Lab of Electronics Physics to Support Teaching and Learning" in J. García Zubía and G. Alves, G. (eds) "Using Remote Labs in Education". Editorial Universidad de Deusto

[11] S. Marchisio, F. Lerro. "El Laboratorio Remoto FCEIA-UNR: Integración de recursos y trabajo en redes colaborativas para la enseñanza de la Ingeniería”. TICAL 2015. Viña del Mar. Chile. 2015

[12] F. Lerro, P. Orduña, S. Marchisio, J. García-Zubía. "Development of a Remote Laboratory Management System and Integration with Social Networks". iJES Vol 2 No 3. 2014. eISSN: 2197-8581. http://onlinejournals.org/index.php/i-jes/issue/view/218.
[13] C. Arguedas Matarrita, S. Concari, F. Ureña Elizondo. "Cooperación latinoamericana para el desarrollo de laboratorios remotos para la enseñanza de la física en ciencias e ingeniería. Actas Congreso Argentino de Ingeniería CADI-CAEDI 2016, 1278-1287. ISBN: 978950-42-0173-1.ftp://ftp.frre.utn.edu.ar/Libro\%20de \%20Actas\%20CADICAEDI\%202016.pdf

[14] P. Orduña, F. Lerro, P. Bailey, S. Marchisio, K. De Long, E. Perreta, O. Dziabenko, I. Angulo, D. Lopez-de-Ipina, J. Garcia-Zubia. "Exploring complex remote laboratory ecosystems through interoperable federation chains," (EDUCON), IEEE, 1200-1208, 2013. ISSN: 2165-9559; http://ieeexplore.ieee.org/stamp/stamp.jsp?tp=\&arnumber=6530259\&isn umber $=6530074$

[15] M. I. Pozzo, E. Dobboletta, M. C. Viegas, M. A. Marques, N. Lima, G. R. Alves, "Diseño de instrumentos para la recolección de información durante la implementación del laboratorio remoto VISIR en Latinoamérica," 1er. Congreso Latinoamericano de Ingeniería (CLADI 2017). Entre Ríos, Argentina, 13-15, Sept., 2017

[16] https://weblab.deusto.es/website/

[17] https://web.fceia.unr.edu.ar/es/noticias-fceia/1123-se-puso-en-marchael-laboratorio-remoto-visir-en-la-fceia.html

[18] S. Marchisio, D. Crepaldo, F. Del Colle, F. Lerro, S. Concari, D. León, C. Merendino, L. Rumin, J. Ghorghor, M. Plano, H. Coscia, U. Hernández Jayo, J. García Zubía, G. Alves. "VISIR lab integration in Electronic Engineering: An institutional experience in Argentina", 2018 XIII Technologies Applied to Electronics Teaching Conference (TAEE), La Laguna, Spain, 20-22/6/18, 289-299. eISBN: 978-1-5386-0928-6 http://ieeexplore.ieee.org/stamp/stamp.jsp?tp=\&arnumber=8476079\&isn umber $=8475971$

[19] I. Evangelista, J. Farina, S. Marchisio, S. Concari, F. Lerro, M. I. Pozzo, G. Alves, J. García Zubía, U. Hernández, K. Nilsson, "Preparando estudiantes secundarios para carreras de ingeniería: un estudio de caso utilizando el laboratorio remoto VISIR". COBENGE 2017: "Inovação no Ensino/Aprendizagem em Engenharia", Joinville/SC, Brasil, 2629/9/17. goo.gl/xXMqsu

[20] I. Evangelista, J. Farina, M. Cadierno, G. Roldán, M. I. Pozzo, E. Dobboletta, J. García Zubía, U. Hernández, G. R. Alves, S. Marchisio, S. Concari, K. Nilsson, "Active learning on DC circuits: spreading the use of VISIR remote lab in Argentina", 2nd IEEE World Engineering Education Conference (EDUNINE), Buenos Aires, Argentina, 11-14 March 2018

[21] I. Evangelista, J. Farina, M. I. Pozzo, E. Dobboletta, G. Alves, J. GarcíaZubía, U. Hernández, S. Marchisio, S. Concari, I. Gustavsson, "Science education at high school: A VISIR remote lab implementation". 4th Experiment@International Conference - exp. at'17. IEEE Xplore. 13-17 http://ieeexplore.ieee.org/xpl/mostRecentIssue.jsp?punumber=7976667

[22] U. Hernandez-Jayo, J. Garcia-zubia, A. Francisco Colombo, S. Marchisio, S. B. Concari, F. Lerro, M. I. Pozzo, E. Dobboletta, G. Alves, "Spreading the VISIR Remote Lab Along Argentina. The Experience in Patagonia". 14th International Conference on Remote Engeneering and Virtual Instrumentation (REV2017). Alemania. Berlín. 2017

[23] J. A. Farina, I. Evangelista, S. B. Concari, M. I. Pozzo, E. Dobboletta, J.r Garcia-Zubia, G. R. Alves, U. Hernadez, S. Marchisio, "Análisis de la idoneidad de una intervención didáctica para la enseñanza de ley de Ohm, en el nivel universitario básico: uso de laboratorio remoto" Revista de Enseñanza de la Física. V. 29, No. Extra, Nov. 2017, 99-111, https://revistas.unc.edu.ar/index.php/revistaEF/article/view/18450/18292

[24] C. Arguedas-Matarrita; S. B. Concari; J. García-Zubía; S. T. Marchisio; U. Hernández-Jayo; G. R. Alves; I. Uriarte-Canivell; M. Conejo Villalobos; I. Gustavsson; F. Ureña Elizondo, "A teacher training workshop to promote the use of the VISIR remote laboratory for electrical circuits teaching". $4^{\text {th }}$ Experiment@International Conference exp. at'17. Published in IEEE Xplore. 1-6. 2017 http://ieeexplore.ieee.org/xpl/mostRecentIssue.jsp?punumber=7976667

[25] C. Viegas, A. Pavani, N. Lima, A. Marques, I. Pozzo, E. Dobboletta, V. Atencia, D.1 Barreto, F. Calliari, A. Fidalgo, D. Lima, G. Temporão, G. Alves, "Impact of a remote lab on teaching practices and student learning", Computers \& Education, Volume 126, 2018, Pages 201-216, ISSN 0360-1315, https://doi.org/10.1016/j.compedu.2018.07.012. http://www.sciencedirect.com/science/article/pii/S0360131518301878 